\title{
Autecology of the diatom Pseudonitzschia australis, a domoic acid producer, from Monterey Bay, California
}

\author{
K. R. Buck ${ }^{1}$, L. Uttal-Cooke ${ }^{1}$, C. H. Pilskaln ${ }^{1}$, D. L. Roelke ${ }^{2}$, M. C. Villac ${ }^{2}$, \\ G. A. Fryxell ${ }^{2}$, L. Cifuentes ${ }^{2}$, F. P. Chavez ${ }^{1, *}$ \\ ${ }^{1}$ Monterey Bay Aquarium Research Institute, 160 Central Avenue, Pacific Grove, California 93950, USA \\ ${ }^{2}$ Department of Oceanography, Texas A\&M University, College Station, Texas 77843, USA
}

\begin{abstract}
Pseudonitzschia australis Frenguelli has been identified as the domoic acid producer responsible for pelican mortalities and shellfish and other seafood quarantines on the west coast of the United States. During autumn 1991, Monterey Bay was the focus of the highest reported concentration of domoic acid in shellfish and anchovies. P. australis has been identified as an important and persistent component of the phytoplankton assemblage in Monterey Bay and contiguous waters for the past $3 \mathrm{yr}$. High abundances occurred consistently in the autumns of 1988 to 1991, as well as in March 1990 and July 1991. Maximum abundance, recorded in November 1991, was in excess of $6 \times 10^{5}$ cells $1^{-1}$. Per cell domoic acid concentrations in October and November 1991 ranged from 3 to 31 pg and water column burdens ranged from 0.1 to $6.7 \mu \mathrm{g} \mathrm{l}^{-1}$. In their tissues, anchovies contained quantities of domoic acid equivalent to $2 \mathrm{~d}$ worth of ration, implying high incorporation and/or low depuration rates.
\end{abstract}

\section{INTRODUCTION}

The mortality of more than 100 brown pelicans in September 1991 in the vicinity of Santa Cruz, in Monterey Bay, (California, USA) (Work et al. 1992) and the subsequent closing of shellfish and crab harvesting in November 1991 in Oregon and Washington (Anon. 1991), has been attributed to the presence of domoic acid in these coastal waters. Domoic acid is a neuroexcitatory amino acid related to glutamic and kainic acids (Addison \& Stewart 1989). It was known to be a product of some seaweeds (Takemoto \& Daigo 1958), but was more recently shown to be produced by phytoplankton (Subba-Rao et al. 1988). Prior to the reports from the west coast of North America, the only other natural occurrence of this compound, in concentrations sufficient to impact higher trophic levels, had been from Prince Edward Island, Canada. In Canada, the toxin producer was the pennate diatom Nitzschia pungens Grunow f. multiseries Hasle, cultured blue mussels Mytilis edulis Linnaeus concentrated the toxin

\footnotetext{
- Addressee for correspondence
}

(Bates et al. 1989, Addison \& Stewart 1989), and the affected organisms were humans. The epidemiology of the Monterey Bay outbreak was different in many respects: the toxin producer was suspected to be a species closely related to $N$. pungens, Pseudonitzschia australis Frenguelli (= Nitzschia pseudoseriata Hasle), the toxin was concentrated in anchovies (Work et al. 1992), and birds were the affected species.

From the standpoint of public health issues, fisheries, and phytoplankton bloom dynamics, it is important to determine the source of the toxin and understand the autecology of the proposed toxin producer. Aspects of the temporal and spatial distribution of Pseudonitzschia australis, and of its absolute abundance, relative contribution to phytoplankton biomass, potential grazers/vectors, flux out of the euphotic zone, environmental constraints, capacity to produce toxin, life cycle and taxonomy all need to be addressed in order to better understand this phenomenon and to put it into a historical perspective.

In an attempt to better understand the ecology of Monterey Bay and the contiguous waters of the California Current, several research projects were initiated 


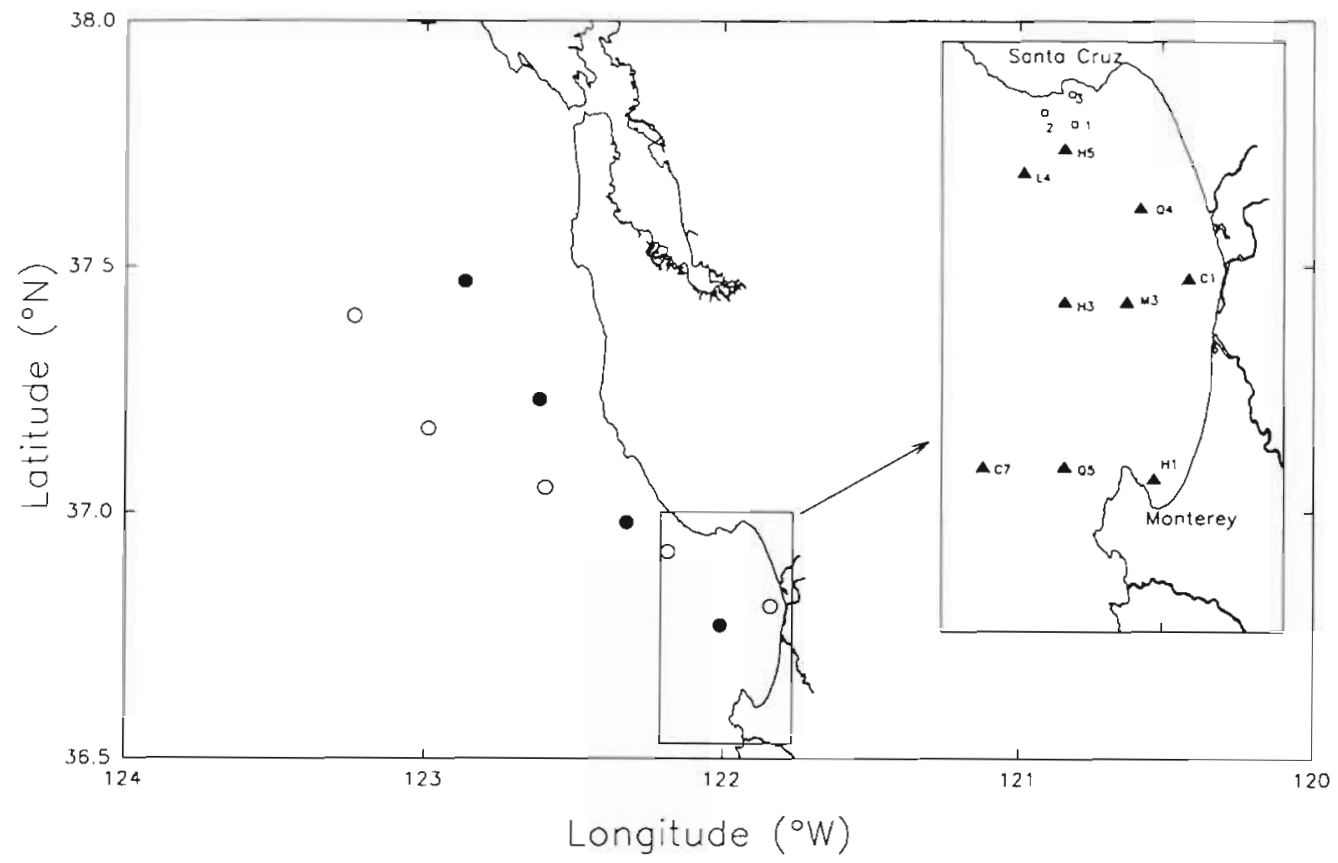

Fig. 1. Monterey Bay and contiguous waters. (A) Stations at which samples were taken on a bimonthly basis, (0) samples taken from the vicinity of Santa Cruz on October 23, 1991 for domoic acid determination, (•) (o) samples obtained on transects on October 25 and November 3, 1991 respectively from the Farallon Islands to Monterey Bay. Sediment trap S1 is located $2 \mathrm{~km} \mathrm{~W}$ of $\mathrm{Stn} \mathrm{H}_{3}$

in 1989 at the Monterey Bay Aquarium Research Institute. Among these were: a bimonthly upper water column sampling regime at selected stations; underway measurement of physical-chemical-biological parameters between these stations; continuous measurement of fluorescence and physical parameters at 2 moorings sites; measurement of flux out of the upper water column using particle interceptor traps; and collection of deep-water animals using a remotely operated vehicle (ROV). The accumulated data from these projects allows us to put the occurrence of Pseudonitzschia australis and its toxicity into a unique perspective and thereby address, in a preliminary manner, some of the critical questions concerning the phenomenon.

\section{ENVIRONMENTAL SETTING}

Monterey Bay is located at the edge of the California Current, on the eastern boundary of the North Pacific gyre. Northwesterly upwelling-favorable winds prevail during most of the year, with their highest intensity during late spring (Nelson 1977, Strub et al. 1987). Three oceanographic seasons have been defined for Monterey Bay: (1) upwelling, (2) oceanic and (3) Davidson (Skogsberg 1936, Bolin \& Abbott 1963). (1) Cold water is often found in the central and outer portions of the bay during the upwelling season, while warm water is found inside the bay in a narrow band nearshore (Bigelow \& Leslie 1930, Skogsberg 1936, Bolin \& Abbott 1963). (2) The oceanic season follows the upwelling season and is characterized by the warmest sea surface temperatures and increased stratification. Autumn and spring are transition times between the 'upwelling' regime and the winter period. (3) During winter, horizontal and vertical thermal gradients are reduced and the Davidson Current flows over the shelf and slope in a predominantly northward direction along the central California coast (Skogsberg 1936. Hickey 1979, Chelton 1984).

The high primary productivity resulting from coastal upwelling, combined with diverse habitats such as kelp forests, rocky shores, sandy beaches, and a deep submarine canyon, results in an abundance of living resources that have made Monterey Bay an important commercial fishing site on the coast of California. During 1989 over 6800 metric tons (t) of squid, $1800 t$ of rockfish, $900 \mathrm{t}$ of anchovies and $450 \mathrm{t}$ of salmon were landed in or around the bay (Wild 1990).

\section{MATERIALS AND METHODS}

The locations of stations sampled on a bimonthly basis in Monterey Bay are shown in Fig. 1. CTD casts were taken at these 9 stations and standard hydrographic and nutrient data collected. Stns C1, H1 and H3 have been sampled repeatedly since 1989 and provide the primary focus of the phytoplankton work. C1 and $\mathrm{H} 1$ are shallow and coastal while $\mathrm{H} 3$ is a deeper water station. Water samples drawn from the upper $200 \mathrm{~m}$ of the water column at these stations were used to characterize the phytoplankton community. Chlorophyll a, primary productivity, particulate organic carbon and biomass of bacterial and protistan components of the assemblage were measured using protocols described in Chavez et al. (1991). Additional surface 
samples outside our normal grid, used solely for enumeration of Pseudonitzschia australis, were taken from several stations in the bay and on 2 transects from the Farallon Islands to Monterey Bay during October-November 1991 (Fig. 1).

For this paper, the analysis was confined primarily to the biomass components of the assemblage, assayed with epifluorescence microscopy (EFM) ( $n=202)$, and the relative abundance of species of the Nitzschia seriata complex (Hasle 1972), assayed with a combination of light (LM) and scanning electron microscopy (SEM), from selected samples $(n=19)$. Although EFM is seldom used for total assemblage enumeration [it is usually used in concert with the Utermöhl settling technique (Reid 1983), with the latter being used to quantify and identify larger more robust organisms such as diatoms and tintinnids], diatoms can be resolved with the epifluorescence slide preparation technique we employ (Chavez et al. 1991). While lacking some of the frustule resolution that is characteristic of phase contrast transmitted light microscopy and important in assigning organisms to species rank, epifluorescence miscroscopy allows genus and in some cases species identification. Cell size and shape, chloroplast morphology and degree of valve overlap are all discernible with EFM.

Samples used for the determination of the relative abundance of species of the Nitzschia seriata complex were cleaned of organic material (Hasle \& Fryxell 1970), mounted in Hyrax and viewed with an oil immersion $100 \times$ objective (Table 1). These included samples from sediment traps collected during August to October 1989 from a Honjo-type trap (Honjo \& Doherty 1988) moored at $500 \mathrm{~m}$ depth $(n=5)$ and during May to August 1990 from an Anderson-type trap (Anderson et al. 1987) moored at $450 \mathrm{~m}(\mathrm{n}=4)$, and from surface $35 \mu \mathrm{m}$ phytoplankton net tows $(n=10)$. A subset of these samples were mounted on aluminum stubs, coated with gold-palladium and viewed with SEM. The sediment trap and net tow samples listed in Table 1 , as well as 2 additional net tows from November 1991, were also enumerated for absolute abundances of species of the $N$. seriata complex using the Utermöhl technique.

Over 50 specimens of Poeobius meseres Heath, a suspension-feeding midwater polychaete, were collected between November 1990 and November 1991 from depths ranging from 260 to $500 \mathrm{~m}$, using an ISE (International Submarine Engineering, Vancouver, BC, Canada) ROV modified for oceanographic research (Etchemendy \& Davis 1991). Fore and hind guts of $P$. meseres were dissected from the individual, teased apart and placed in a settling chamber for enumeration on an inverted microscope. All recognizable organisms and fecal pellets were tallied and sized.

Aliquots of the surface phytoplankton net tows (2 to
Table 1. Net tows and sediment trap samples from Monterey Bay for which relative abundance counts of species of the Nitzschia seriata complex were done $\mathrm{n}=50$ whole valves or fragments (sediment traps) per sample except for Q5 where only 35 valves were found

\begin{tabular}{|c|c|c|c|}
\hline \multirow{2}{*}{$\begin{array}{l}\text { Sample Lo } \\
\text { Sediment trap }\end{array}$} & \multirow{2}{*}{ Location } & \multirow[t]{2}{*}{ Date } & $\begin{array}{l}\text { Pseudo- } \\
\text { chia australis }\end{array}$ \\
\hline & & & \\
\hline$\# 1$ & S1 & Aug 23 - Sep 6, 1989 & 100 \\
\hline$\# 2$ & $\mathrm{~S} 1$ & Sep 6-Sep 20, 1989 & 98 \\
\hline$\# 3$ & $\mathrm{~S} 1$ & Sep 20-Oct 4,1989 & 98 \\
\hline$\# 4$ & $\mathrm{~S} 1$ & Oct $4-$ Oct 18,1989 & 100 \\
\hline$\# 5$ & $\mathrm{~S} 1$ & Oct $18-$ Nov 1,1989 & 98 \\
\hline$\# 6$ & S1 & May 5-May 19, 1990 & 80 \\
\hline$\# 7$ & S1 & May 19-Jun 2, 1990 & 86 \\
\hline$\# 9$ & $\mathrm{~S} 1$ & Jun $16-$ Jun 30,1990 & 96 \\
\hline$\# 13$ & $\mathrm{~S} 1$ & Aug 11-Aug 20, 1990 & 96 \\
\hline \multicolumn{4}{|c|}{ Net tows } \\
\hline & H3 & May 4, 1990 & 36 \\
\hline & L4 & Oct 16,1991 & 100 \\
\hline & 1 & Oct 20,1991 & 98 \\
\hline & 2 & Oct 20,1991 & 100 \\
\hline & 3 & Oct 20,1991 & 98 \\
\hline & $\mathrm{H} 3$ & Nov 13,1991 & 100 \\
\hline & L4 & Nov 13,1991 & 100 \\
\hline & Q5 & Nov 13,1991 & 91 \\
\hline \multicolumn{2}{|c|}{ Santa Cruz pier } & Sep 18, 1991 & 100 \\
\hline \multicolumn{2}{|c|}{ Santa Cruz pier } & $\operatorname{Sep} 20,1991$ & 100 \\
\hline
\end{tabular}

5 min at 2 knots with a $25 \mathrm{~cm}$ diameter $35 \mu \mathrm{m}$ mesh net) collected in Monterey Bay during October ( $n=7$ ) and November ( $n=5$ ) 1991 were also frozen for domoic acid assays. The frozen samples were later thawed, sonicated with a Branson B-12 ultrasonic cleaner for $15 \mathrm{~min}$ and filtered through $0.2 \mu \mathrm{m}$ Nuclepore filters. A High Performance Liquid Chromatograph (Gilson, 811B) equipped with ultraviolet detection (ISCO, V4) for measurement of absorption at $242 \mathrm{~nm}$ was used to assay for domoic acid in the plankton samples. Domoic acid (Sigma) dissolved in $10 \%$ aqueous acetonitrile was used as a standard (Fig. 2). A $25 \mathrm{~cm} \times 4.6 \mathrm{~mm}$ (I.D.) Hypersil Ods C18 $5 \mathrm{~mm}$ column (Alltech) was used in the analysis, to run a gradient of 5 to $25 \%$ acetonitrile with $0.1 \%$ trifluoroacetic acid for $20 \mathrm{~min}$. The flow rate was $1.6 \mathrm{ml}$ $\mathrm{min}^{-1}$. The detection threshold of our HPLC was $2.5 \mathrm{ng}\left(0.01 \mathrm{Mg} \mathrm{m}^{-1}\right)$. To verify that we were detecting domoic acid, the peaks from HPLC analysis (Fig. 2) were collected and scanned from 200 to $300 \mathrm{~nm}$ on a Shimadzu UV-1201 spectrophotometer and then analyzed with a fast atom bombardment mass spectrometer (VG-70S). Results were compared with the Sigma domoic acid standard. Domoic acid per cell was calculated by dividing the domoic acid concentration derived from HPLC analysis of frozen net tows by the concentration of Pseudonitzschia australis in the pre- 


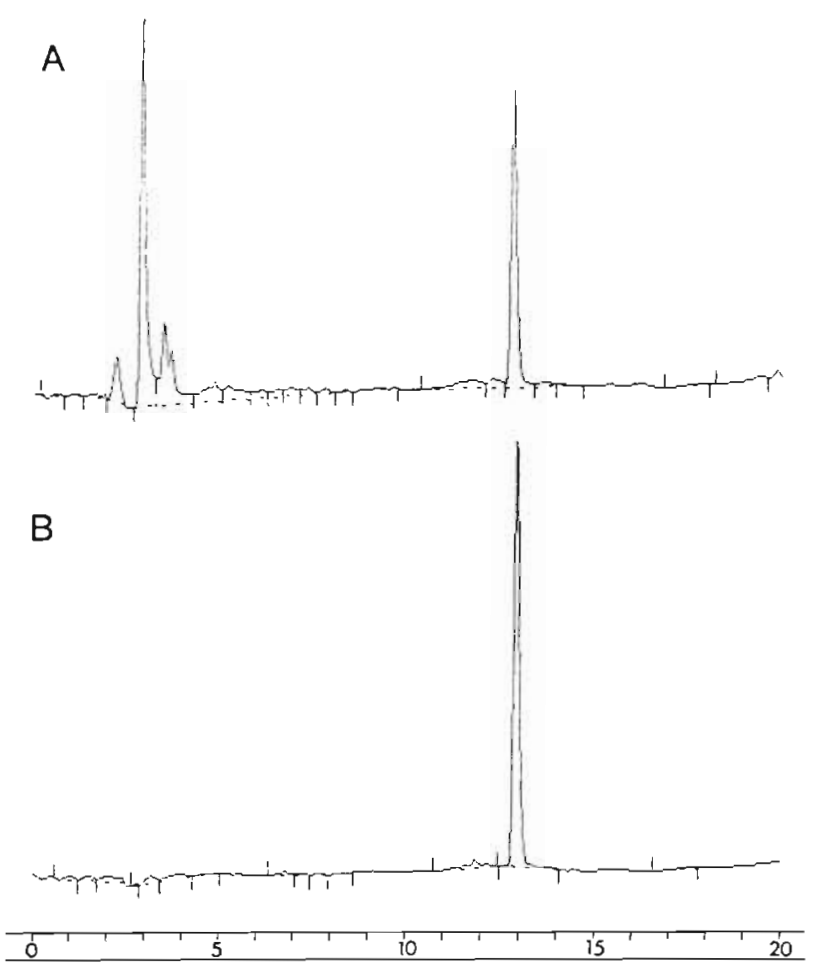

Fig. 2. HPLC chromatographs: (A) Net tow from Monterey Bay in October 1992 (Stn 1) diluted to $10 \%$, initial domoic acid concentration $4.89 \mu \mathrm{g} \mathrm{ml}{ }^{-1}$; (B) sigma domoic acjd standard at $0.80 \mu \mathrm{g} \mathrm{ml^{-1 }}$

served net tow aliquots. Whole water domoic acid concentrations were calculated by multiplying the per cell domoic acid concentration by the abundance of $P$. australis determined from epifluorescence counts of whole water samples.

\section{RESULTS}

\section{Taxonomy and morphology}

Hasle $(1965,1972)$ has described 2 complexes within the section Pseudonitzschia Peragallo: the Nitzschia seriata complex and the Nitzschia delicatissima complex. The species of the $N$. seriata complex, all robust and relatively large, include $N$. seriata Cleve, $N$. fraudulenta Cleve, $P$. australis Frenguelli $(=N$. pseudoseriata Hasle), N. pungens Grunow, N. subfraudulenta Hasle, $N$. subpacifica Hasle, and $N$. heimii Manguin (=N. pacifica sensu Hustedt). The original nomenclature of Frenguelli (1939), who described Pseudonitzschia australis, is used here rather than the name N. pseudoseriata Hasle. Round et al. (1990) have suggested utilizing some sections of Nitzschia at higher levels and many nomenclatural changes within this genus are under study (Hasle unpubl.).

The size range of Pseudonitzschia australis is 75 to $144 \mu \mathrm{m}$ in length, and 6.5 to $8 \mu \mathrm{m}$ in valve width. It possesses 12 to 18 fibulae and costae per $10 \mu \mathrm{m}$ and has 2 rows of poroids per costa (Hasle 1965) (Figs. 3 to 11). Nitzschia seriata is another taxon in the $N$. seriata complex that overlaps the dimensions of $P$. australis, one difference being 3 to 5 rows of poroids per costa (Hasle 1965). The shape of $P$. australis is long and lanceolate (Figs. 5 to 7,11 ) with the fibulae (arched supports) in approximately the same number as costae (Figs. $3,8,9$ ). From the outside of the cell the poroids are visible when the valve is slightly eroded as frequently seen in sediment trap material (Fig. 10). P. australis is listed as having a southern hemisphere distribution (Hasle 1965). However, 2 questionable records from Monterey Bay (Hasle 1972) were later confirmed (Hasle pers. comm.). The 1967 sample collected by Hasle from Monterey Bay also contained $N$. heimii, $N$. pungens f. multiseries and either $N$. fraudulenta or $N$. subfraudulenta (Hasle pers. comm.). $P$. australis collected in the middle of the bay in September 1991 averaged $( \pm \mathrm{SD}, \mathrm{n}=21) 105.5$ $( \pm 3.8) \mu \mathrm{m}$ in length, $7.5( \pm 0.4) \mu \mathrm{m}$ in width and 5.1 $( \pm 0.4) \mu \mathrm{m}$ in pervalvar axis. Maximum chain length was 90 cells, observed at the northern station on the November 3, 1991 transect (Fig. 1).

\section{Abundance and distribution}

Abundances of Pseudonitzschia australis within Monterey Bay exhibited a distinct seasonal pattern throughout the period of study, with peaks occurring

Figs, 3 to 11. The diatom Pseudonitzschia australis Frenguelli, scanning electron micrographs, Monterey Bay, California. Figs. 3 \& 4. Same specimen from $35 \mu \mathrm{m}$ mesh net haul, May 4, 1990, H3. Biological inside view of single valve. Note 2 rows of poroids between more heavily silicified costae. Valve with long, tapered shape with one margin slightly more curved than the other. Fig. 5. Specimen recovered from the gut of the mid-water polychaete Poeobius meseres. At the bottom of the micrograph, note the broken overlapping tip of sibling valve, showing type of colony formation that provides a good field character. Fig. 6. Almost intact specimen from sediment trap cup $\$ 5$ of mooring S1, October 1989. Figs. 7 \& 8 . Inside view of same valve from Stn 3 (see Fig. 1). October 1991 net haul, cleaned of organic matter. Note typical outline of valve with one margin slightly more curved than the other. Detailed micrograph shows the slit or raphe on which the diatom can move, beneath the silica arches or fibulae. Fig. 9. Same well-preserved specimen as in Fig. 4. Note consistent pore size and configuration. Figs. 10 \& 11. Outside view of same slightly eroded specimen from sediment trap cup \#1 of mooring S1, August 1989, showing pores in doublet rows, the raphe, or sljt, at the top left of the micrograph, and the marginal leaf-like pores bridging the doublets at the bottom right. Scale bars $=1 \mu \mathrm{m}$ for Figs. 3, 8, $9 \& 10$, and $10 \mu \mathrm{m}$ for Figs. 4 to 7,11 


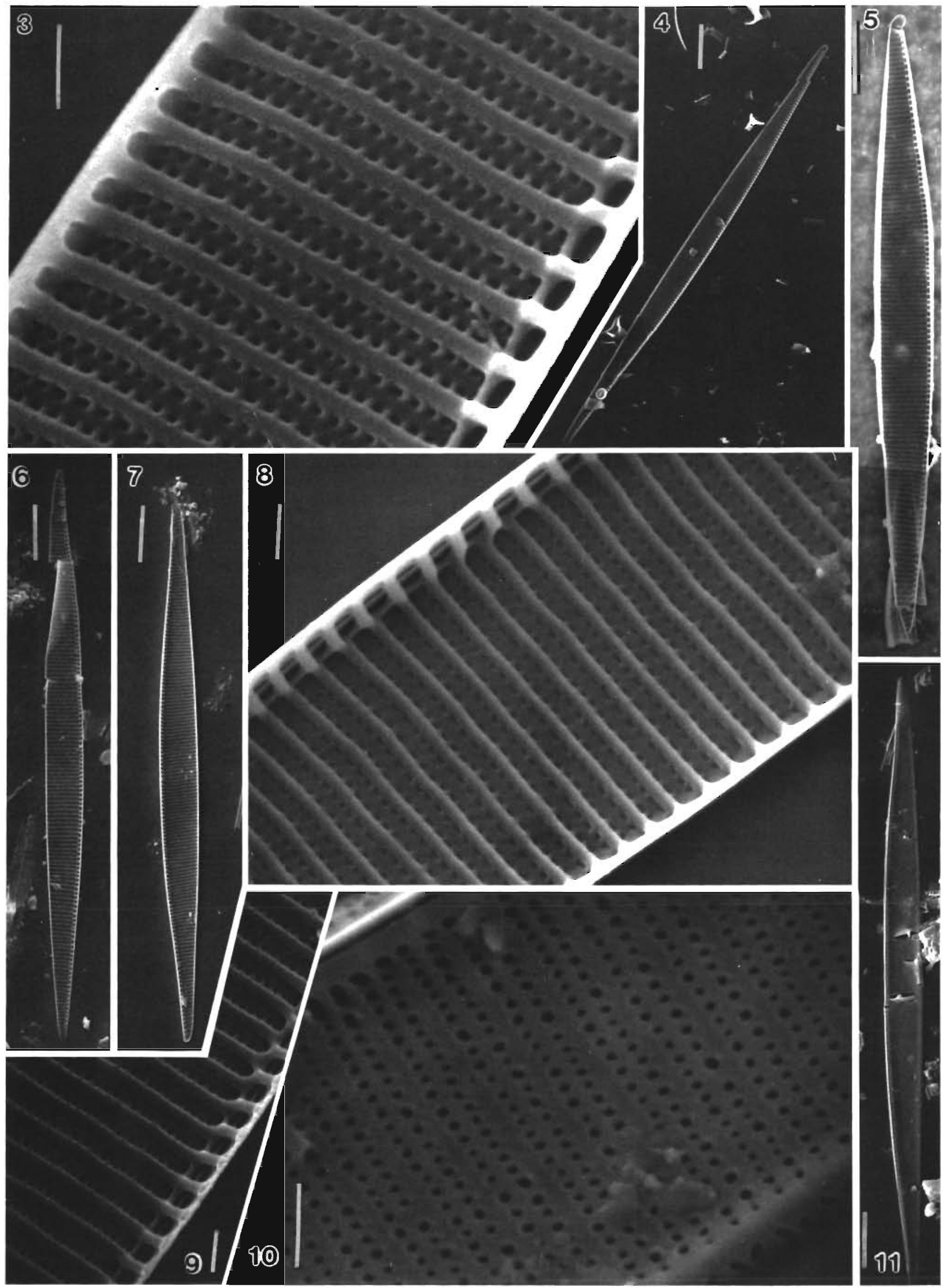


during the autumns of 1989,1990 and 1991. In addition to the obvious autumn maxima there were high abundances in spring 1990 and summer 1991 (Fig. 12). Maximum abundance and biomass, in excess of $6.7 \times$ $10^{5}$ cells $1^{-1}$ and $216 \mu \mathrm{gC}^{-1}$ respectively, were recorded from Stn H3 during November 1991 (Fig. 13). During a significant portion of the year, no $P$. australis cells were observed in our enumerations (Fig. 12). The contribution of $P$. australis to the total autotroph biomass and total diatom biomass at individual stations ranged from 0 to $87 \%$ and 0 to $89 \%$, respectively (Fig. 12). The absolute biomass maxima coincided with the periods of maximum relative abundance of $P$. australis, except for the July 1991 biomass maximum.

In the 19 cleaned and Hyrax-mounted samples assayed with an oil immersion $100 \times$ phase contrast objective and SEM, the preponderance ( 36 to $100 \%$ ) of valves of the Nitzschia seriata complex were identified as Pseudonitzschia australis (Table 1). The sample with only $36 \%$ of the complex composed of $P$. australis was from spring 1990. This sample was numerically dominated by $N$. subpacifica, a species with a length that does not overlap that of $P$. australis (Hasle 1965). Other taxa of this genus recorded in this study included $N$. subpacifica, several reports of $N$. pungens and species attributable to the $N$. delicatissima complex (Hasle 1965).

The abundance of Pseudonitzschia australis in surface waters on a 4-station transect between the Farallon Islands and Monterey Bay conducted on October 25, 1991 ranged from 2.4 to $27 \times 10^{4}$ cells $l^{-1}$, with highest abundances found in Monterey Bay. On a similar 5-station transect occupied on November 3 , 1991, surface abundances ranged from 1.2 to $33 \times 10^{4}$ cells $1^{-1}$ with highest abundances found in the vicinity of the Farallons. At a mid-bay station sampled on October 29, November 7, December 5 and December 10 , 1991 abundances of $P$. australis were 4.3,11, 4.3 and $0 \times 10^{4}$ cells $l^{-1}$ respectively.

Relative abundances of Pseudonitzschia australis in individual guts of Poeobius meseres ranged from 0 to $78 \%$ and, as with the upper water column data, high abundances occurred in the autumns of 1990 and 1991 (Fig. 14). Sediment trap samples from August through October 1989 also showed an increase in $P$. australis in the autumn. Valve flux ranged from $10^{5}$ to $9 \times 10^{6}$ valves $\mathrm{m}^{-2} \mathrm{~d}^{-1}$ over this $70 \mathrm{~d}$ period, accounting for upwards of $80 \%$ of the valves enumerated in the first 4 sampling periods (Fig. 15). During spring and summer $1990, P$. australis valve flux to $450 \mathrm{~m}$ ranged from $1.3 \times 10^{6}$ to $6.4 \times 10^{7}$ valves $\mathrm{m}^{-2} \mathrm{~d}^{-1}$ and accounted for up to $39 \%$ of the total diatom valve flux (Fig. 15).

\section{Domoic acid content of phytoplankton}

Domoic acid concentration in the phytoplankton net tows collected during October 1991 in the northern part of the bay ranged from 1.9 to $4.89 \mu \mathrm{\mu g} \mathrm{ml} \mathrm{m}^{-1}$ (Table 2) while abundances of Pseudonitzschia australis in the water column ranged from 6.5 to $20 \times 10^{4}$ cells $\mathrm{I}^{-1}$. Assuming that all the domoic acid was in the cells of $P$. australis, then the content per cell ranged from 12 to $31 \mathrm{pg}$ and concentration in the water column ranged from 1.1 to $2.4 \mu \mathrm{g} \mathrm{I}^{-1}$. Phytoplankton net tows taken in mid November 1991 from throughout the bay yielded domoic acid concentrations of 0.1 to $14.5 \mu \mathrm{g} \mathrm{ml}^{-1}$ (Table 2); abundances of $P$. australis ranged from 0.8 to $67.0 \times 10^{4}$ cells $\mathrm{l}^{-1}$. Domoic acid content per cell ranged from 3 to $18 \mathrm{pg}$ and concentration in the water column ranged from 0.1 to $6.7 \mu \mathrm{g} \mathrm{l}^{-1}$.
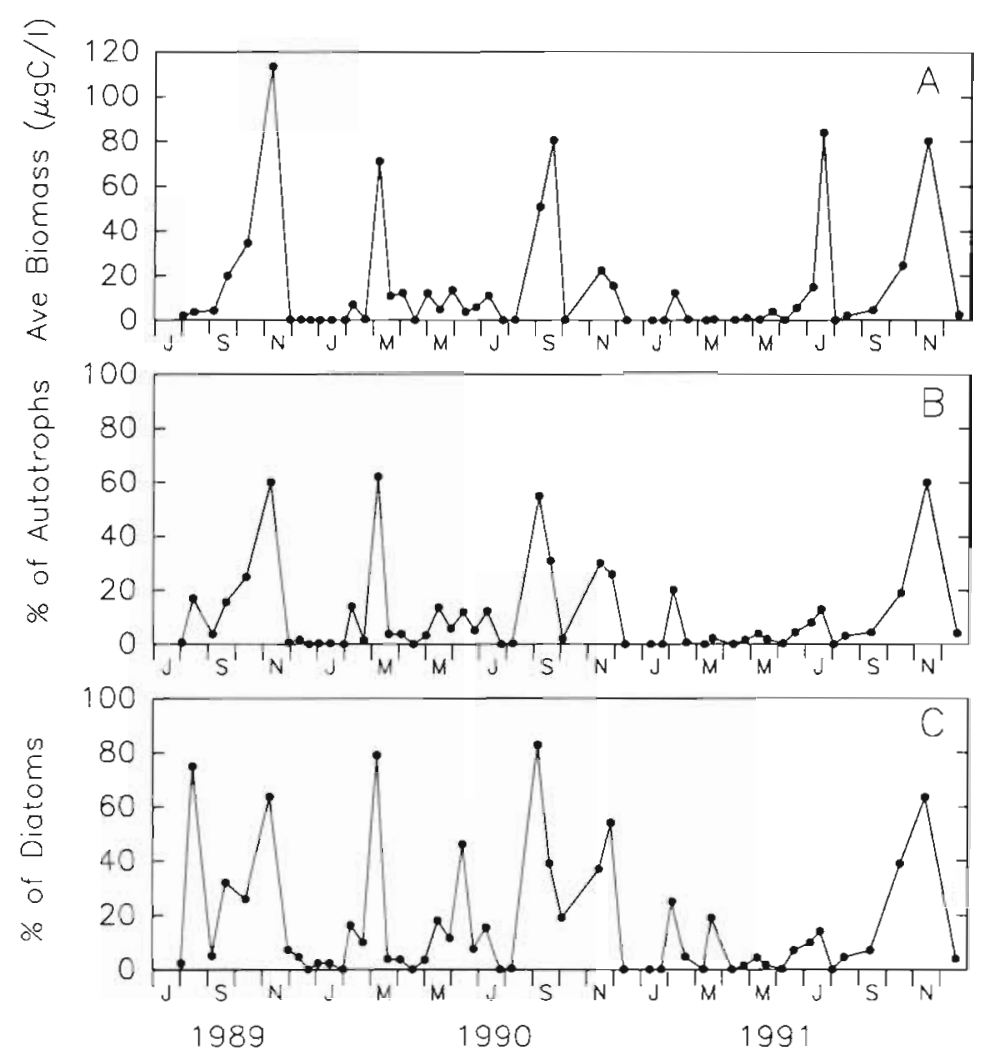

Fig. 12. Pseudonitzschia australis. Seasonal variation in biomass during 1989 to 1991 at 3 stations in Monterey Bay (C1, H3, H1). Biomass was determined from EFM counts. (A) Average biomass. Values for sampling dates in October and November 1991 represent averages for 8 and 6 stations respectively. (B) Percent contribution to total autotroph biomass. (C) Percent contribution to total diatom biomass 


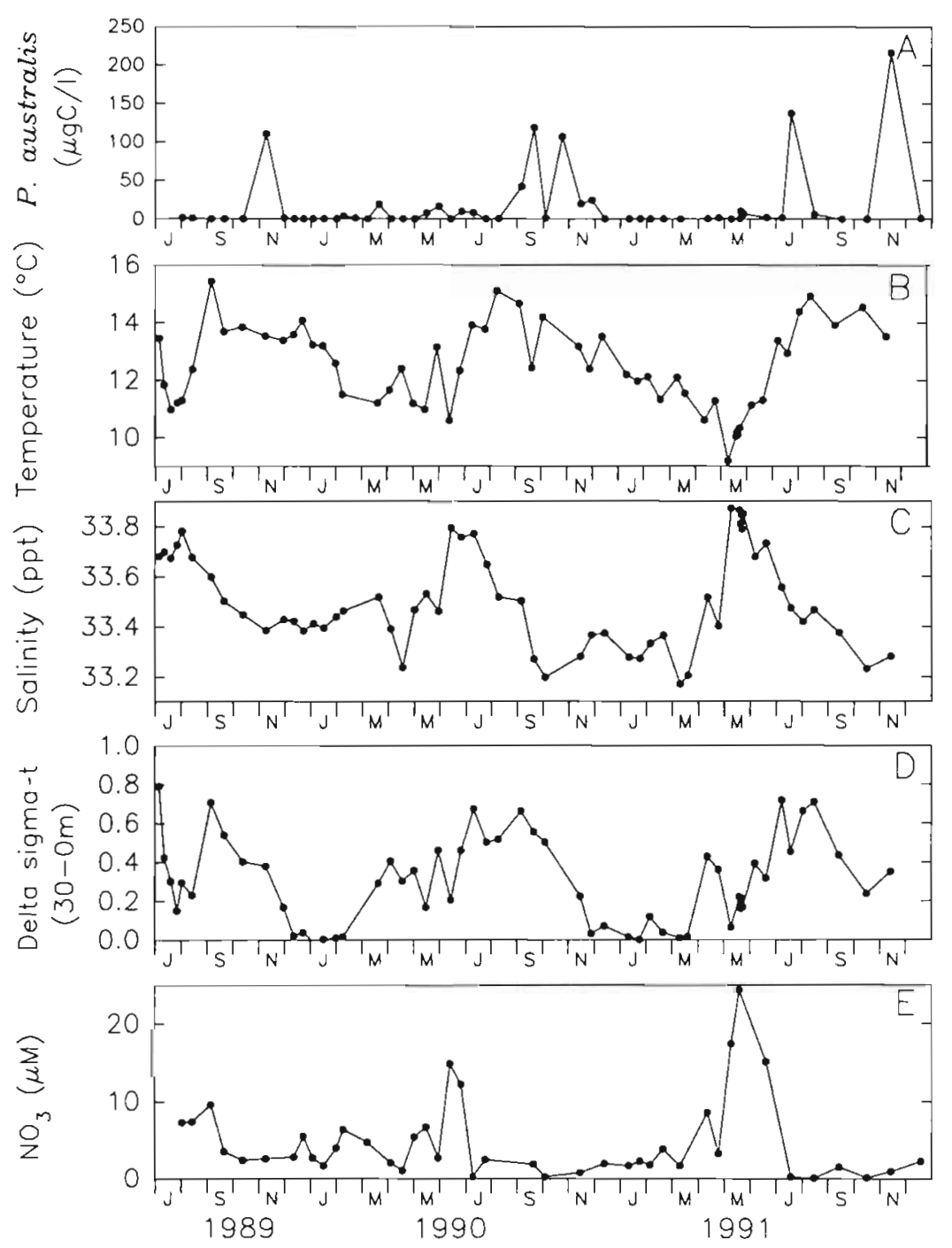

Fig. 13. Pseudonitzschia australis. (A) Biomass from EFM counts; (B) temperature, (C) salinity; (D) delta sigma- $t(30$ to $0 \mathrm{~m})$; and (E) nitrate values $(0 \mathrm{~m})$ from Stn $\mathrm{H} 3$ for 1989 to 1991
Replicate net tows from 3 of the 4 stations yielded domoic acid per cell estimates that varied from the mean concentration from 12 to $21 \%$. A significant correlation $(r=0.64, p<0.05$, $\mathrm{n}=12$ ) was found between $P$. australis abundance and domoic acid concentration in the net tows analyzed for domoic acid.

\section{Relationship to physical and chemical properties}

The waters of Monterey Bay during the major autumn abundance peaks can be characterized as warm (13 to $14^{\circ} \mathrm{C}$ ), moderately well stratified (delta sigma- $t 0.4$ to 0.6 between 0 and $30 \mathrm{~m}$ ), and relatively depleted of nutrients $\left(\mathrm{NO}_{3}<2 \mu \mathrm{M}\right)$ (Fig. 13). The intrusion of well-stratified California Current waters into Monterey Bay punctuated by periodic upwelling characterizes the oceanography of the bay during September to November and this is followed by deeper winter mixing (Bolin \& Abbott 1963). Correlation analysis between temperature, salinity, nitrate, and carbon biomass of Pseudonitzschia australis for Stn $\mathrm{H} 3$ yielded low but significant correlations between salinity and temperature and biomass (salinity, $r=-0.41, p<0.01$; temperature, $r=0.54, p<0.005$ ). However, although $P$. australis is positively correlated with temperature (i.e. maximum abundance is during the warmer
Fig. 14. Relative abundance of Pseudonitzschia australis in the gut of Poeobius meseres collected at depth in Monterey Bay November 1990 to November 1991

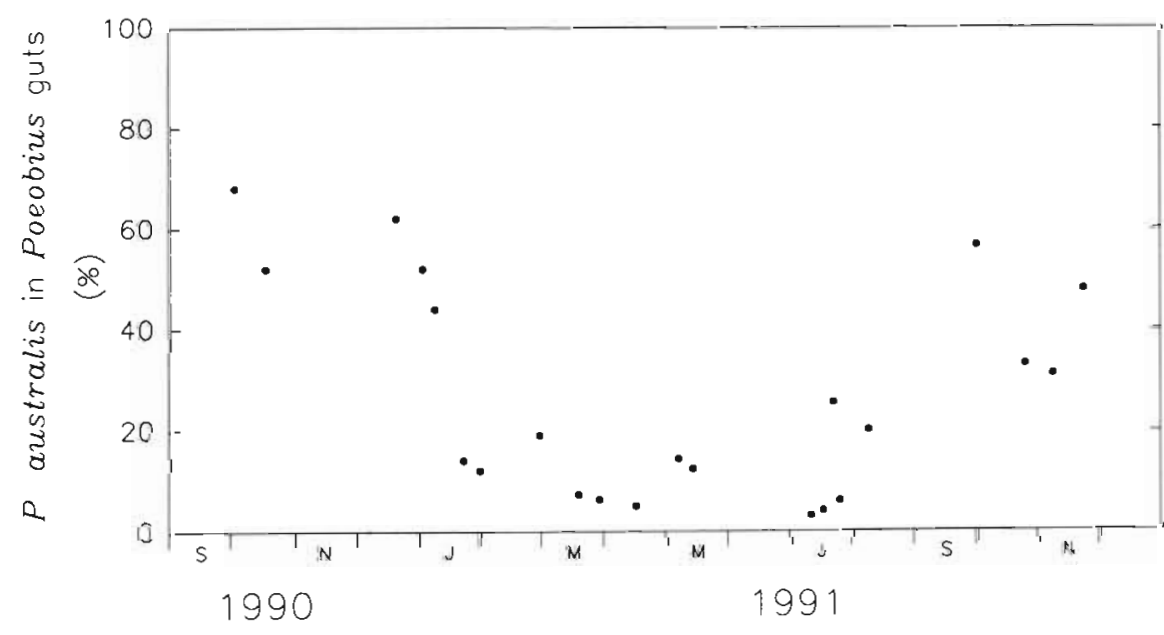



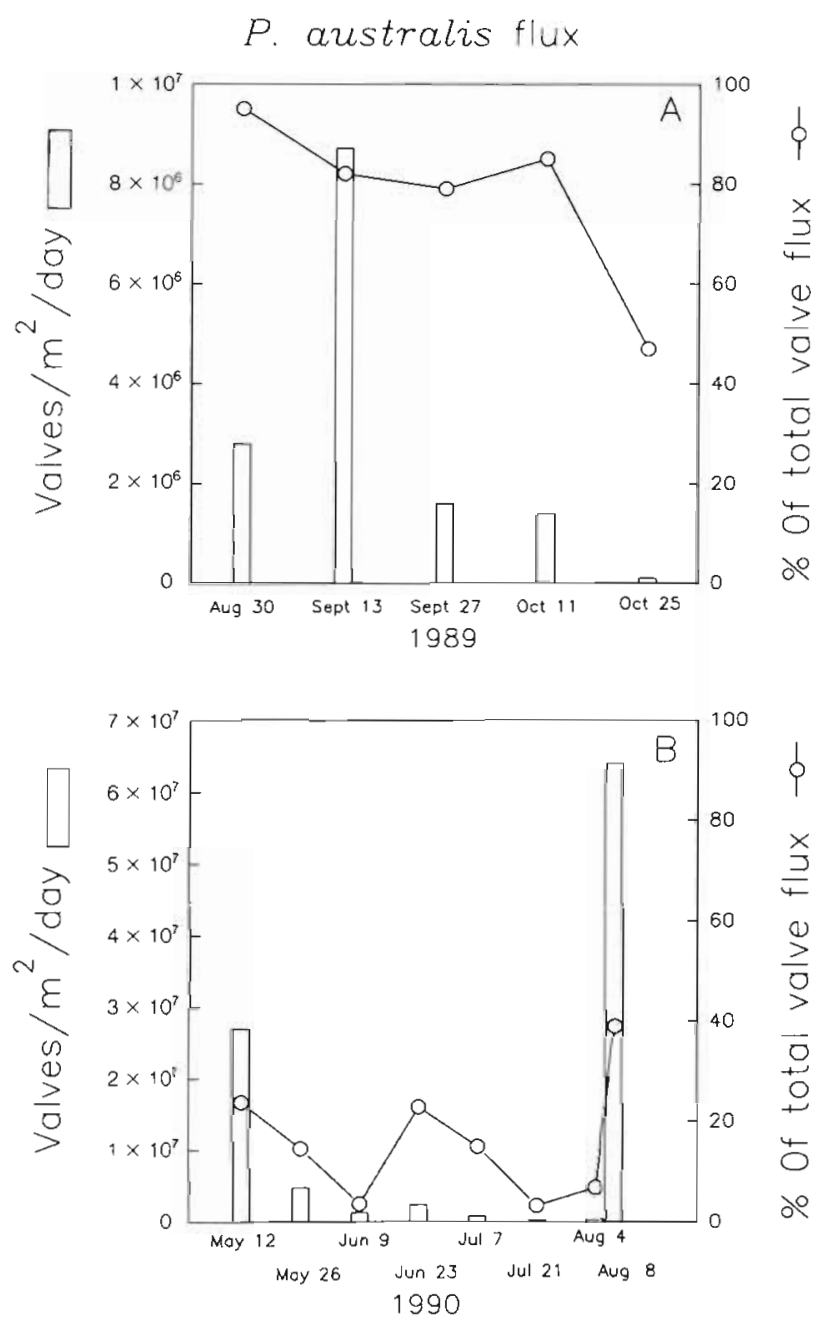

Fig. 15. Pseudonitzschia australis. Absolute and relative abundances in moored sediment traps from (A) autumn 1989, and (B) spring-summer 1990

Table 2. Domoic acid content of net tow samples collected in Monterey Bay, October and November 1991. Concentrations of domoic acid in whole water is calculated from the mean of 2 determinations of domoic acid per cell for Stns 1 to 3

\begin{tabular}{|ccccc|}
\hline Station & $\begin{array}{c}\text { Date } \\
(1991)\end{array}$ & $\begin{array}{c}\text { Net tow } \\
\left(\mu \mathrm{g} \mathrm{ml}^{-1}\right)\end{array}$ & $\begin{array}{c}\text { Per cell } \\
\left(\mathrm{pg} \mathrm{cell}^{-1}\right)\end{array}$ & $\begin{array}{c}\text { Whole water } \\
\left(\mu \mathrm{g} \mathrm{I}^{-1}\right)\end{array}$ \\
\hline L4 & Oct 16 & 4.2 & 12 & 2.4 \\
1 & Oct 20 & 3.3 & 21 & 2.0 \\
1 & Oct 20 & 5.5 & 31 & \\
2 & Oct 20 & 4.9 & 15 & 1.1 \\
2 & Oct 20 & 3.9 & 19 & \\
3 & Oct 20 & 1.9 & 12 & 2.0 \\
3 & Oct 20 & 2.2 & 16 & \\
C1 & Nov 13 & 2.2 & 6 & 0.1 \\
H1 & Nov 13 & 3.7 & 3 & 0.7 \\
Q5 & Nov 13 & 0.1 & 18 & 0.1 \\
L4 & Nov 13 & 3.8 & 3 & 0.5 \\
H3 & Nov 13 & 14.5 & 10 & 6.7 \\
\hline
\end{tabular}

time of the year), many of the periods of high abundance are associated with weak upwelling events, reflected in cooling at the sea surface (Fig. 13).

\section{DISCUSSION}

The presence of Pseudonitzschia australis in Monterey Bay and contiguous waters has been confirmed from analysis of samples at multiple stations during several years, both inside and outside the bay. EFM has allowed us to enumerate cells with a Pseudonitzschialike habit (i.e. valves with a stepwise girdle view outline in chains with valve-to-valve overlap) of a size similar to $P$. australis. Examination of cleaned and Hyrax-mounted samples from as many sampling regimes and times available to us provides strong evidence that $P$. australis has been the dominant component of the Nitzschia seriata complex in Monterey Bay, particularly in autumn. Unequivocal identification of $P$. australis dictates the use of SEM on cleaned valves, a technique that does not lend itself to quantification. Combining SEM and high resolution LM viewing of cleaned valves with a quantitative protocol such as EFM or the Utermöhl procedure seems a reasonable compromise. Development of molecular assays for P. australis and/or domoic acid may make this task less cumbersome in the future.

The coincident occurrence of this diatom with domoic acid in the stomach contents of dead pelicans directly implicated it as the producer of the toxin (Work et al. 1992). Production of domoic acid by 2 clones of Pseudonitzschia australis isolated from Monterey Bay confirmed this (Garrison et al. in press). These findings coupled with the positive correlation between $P$. australis abundance and domoic acid concentration in net tows from Monterey Bay for October and November 1991 (Table 2) offer irrefutable evidence that this species was the source of domoic acid in the waters of the northeast Pacific during 1991.

The high relative abundance of this diatom in the guts of Poeobius meseres and in the sediment trap samples indicates that Pseudonitzschia australis is also an important contributor to the flux of material to the ocean floor. The large percentage of intact valves in the deep waters of Monterey Bay indicates that the grazing pressure on this species by predators that triturate their prey (i.e. copepods) may be diminished and/or these organisms are extremely rapid settlers from the euphotic zone. Domoic acid has been shown to have toxic effects upon small copepods (Windhust \& Wright 1991), albeit at concentrations far exceeding the maximum concentration reported from this or other field studies. The presence of copepod (predominantly Calanus pacificus; W. Peterson pers. comm.) and euphausiid fecal pellets filled with fragments of 
P. australis valves taken from Stn $\mathrm{H} 3$ on November 13 , 1991 (unpubl. data) indicates that metazoans are capable of having an impact upon the biomass of this organism.

The physical regime of low salinity and high temperatures, that characterizes the water column in which we find high abundances of Pseudonitzschia australis, indicates that its environmental constraints are different from Nitzschia pungens f, multiseries, the closely related diatom implicated in the domoic acid outbreak in Prince Edwards Island. $N$. pungens f. multiseries has broad environmental tolerances, hence its wide distribution (Hasle 1965, 1972, Fryxell et al. 1992). High precipitation following an unusually dry summer has been suggested as the causative phenomenon for the first domoic acid incident (Bird \& Wright 1989), with the attendant runoff supplying the nitrogen source. Although California had experienced a drought for $5 \mathrm{yr}$ lack of runoff in Central California during spring through autumn is the norm. The likelihood that $P$. australis domoic acid production is somehow tied to this drought is therefore small. The small upwelling events that punctuate the autumn oceanic/winter transition (Bolin \& Abbott 1963) may, however, substitute for freshwater runoff as the nitrogen source.

The per cell domoic acid content that we have recorded is significantly higher than that recorded for Nitzschia pungens from Prince Edwards Island (Bates et al. 1989) and is in the same range reported for cultures of Pseudonitzschia australis (Garrison et al. in press). The difference in cell volume between $P$. australis and $N$. pungens f. multiseries $\left(3714 \mu \mathrm{m}^{3}\right.$ vs $1834 \mu^{3}$ ) probobly accounts for the difference. This ratio implies that a lower abundance of $P$. australis would be capable of producing a significant toxicological effect. Indeed, the highest numbers of $P$. australis recorded in Monterey Bay from discrete samples are about an order of magnitude less than the maxima recorded for $N$. pungens f. multiseries in Canada.

Very high concentrations of domoic acid (max = 2300 ppm; California Department of Health Services unpubl. data) were found in the guts of anchovies taken from Monterey Bay during November 1991 Domoic acid concentrations in the meat of these anchovies were in excess of 50 ppm (Kris Foster pers. comm.). Using a body weight of $8.0 \mathrm{~g}$, conversion factors of 0.175 to dry weight, 0.4 to carbon and a clearance rate of $5 \%$ body weight $\mathrm{fish}^{-1} \mathrm{~d}^{-1}$ (Peterson et al. 1992), we calculate that $91 \mathrm{l}$ of water would be cleared fish $^{-1} \mathrm{~d}^{-1}$. This quantity of water would contain approximately $50 \%$ of the body burden of domoic acid found in the anchovies, assuming the maximum water column concentration of $6.7 \mu \mathrm{g} \mathrm{l}^{-1}$ of domoic acid (Table 2). By comparison, mussels incorporate only 1 to $2 \%$ of the available domoic acid (Madhyastha et al.
1991). Depuration studies with anchovies need to be undertaken before definitive conclusions can be made regarding their capacity to act as a vector for domoic acid. However, it seems that anchovies are much more efficient at sequestering this compound than bivalves. This may explain, in part, why the concentration of

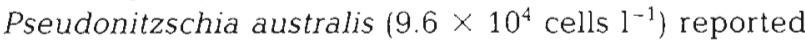
in the water column near the locus of the pelican mortality in Santa Cruz (Work et al. 1992) was so low.

The percent contribution of Pseudonitzschia australis to the net phytoplankton is also an important consideration in the epidemology of domoic acid. For example, high percent contributions may be of more importance than high absolute abundances; therefore total phytoplankton abundance must be determined to adequately assess the potential effect that domoic acid has upon higher trophic levels. The high abundance of $P$. australis in July 1991 (Fig. 12) may not have impacted upon higher food webs because it was diluted by the even higher biomass of predominantly Chaetoceros spp. It is interesting to note that the maximum relative abundance of Nitzschia spp. from Monterey Bay net tows made during 1954 to 1960 rarely exceeded $40 \%$ (Bolin \& Abbott 1963). During our study, the relative abundance of $P$. australis in whole water samples exceeded $50 \%$ (maximum of $89 \%$ ) of the total diatom biomass on 6 occasions (Fig. 12). The large size of $P$. australis and the chains it forms makes this difference even greater. This may be evidence that the dominance of this organism is increasing.

Episodes of unexplained high mortality of pelicans in the central California coast during the autumn of 1971 , 1976 and 1981 have been reported (Stenzel et al. 1988). Although we have no information on the cause of these mortalities, it is possible that they were the result of domoic acid intoxication. The time series data on phytoplankton we have collected, together with historical data (Bolin \& Abbott 1963, Hasle pers. comm.) on the abundance of Nitzschia spp., seem to indicate that $P$ seudonitzschia australis has been a common inhabitant of central California coastal waters. However, $P$. australis appears to possess the capacity to produce variable amounts of domoic acid. This is evident from both the variability of per cell concentrations from natural populations (Table 2) and from data extrapolated from culture work with this species and $N$. pungens f. multiseries (Carrison et al. 1992, unpubl.). In addition, $P$. australis exhibits considerable spatial variability in abundance within the bay, which may, in part, be the result of advective forces. This complicates monitoring, prediction and understanding the processes that contribute to this phenomenon Future work should be multidisciplinary in nature and should emphasize coordinated culture and field studies. 
Acknowledgements. The crews of the RV 'Pt Lobos' and 'Pt Sur', D. Steinberg, D. Heilprin, N. Garfield, L. Lewis, K. Reisenbichler and $J$ Barry were instrumental in obtaining casual samples throughout the autumn of 1991. J. Kogelschatz and C. Zenker collected most of the monthly samples in Monterey Bay. L. Rosenfeld and R. Schramm provided the physical data and $\mathrm{L}$. Codispoti and $\mathrm{C}$. Sakomoto the chemical data. S. Service, L. Lewis, R. Schramm, M. Silver and B. Robison made editorial comments and $W$. Peterson provided identifications of the calanoid copepods as well as insight into anchovy grazing dynamics. G. Hasle graciously provided us with unpublished observations and resurveyed several archived slides to confirm the historical presence of Pseudonitzschia australis in Monterey Bay. Food and Drug Administration, National Marine Fisheries Service and California Department of Health Services provided the domoic acid concentration data for shellfish and anchovies Support was provided to M.C.V. by Conselho Nacional de Desenvolvimento Cientifico e Tecnologico (CNPq) - ref. 201298/ 90-2. This research was made possible by the Texas Institute of Oceanography, a Texas A\&M University Sea Grant Project awarded to G.A.F. and the Lucile and David Packard Foundation through research funds allocated by the Monterey Bay Aquarium Research Institute to F.P.C.

\section{LITERATURE CITED}

Addison, R. F., Stewart, J. E. (1989). Domoic acid and the eastern Canadian molluscan shellfish industry. Aquaculture 77: 263-269

Anderson, R. Y., Hemphill-Haley, E., Gardner, J V. (1987) Persistent late-Pleistocene-Holocene seasonal upwelling varves off the coast of California. Quat. Res. (N.Y.) 28 $307-313$

Anonymous (1991). Domoic acid found in Oregon and Washington shellfish. Communicable Diseases Summary 4O, \#24. Oregon Health Division, Portland

Bates, S. S., Bird, C. J., de Freitas, A. S. W., Foxal, R., Hanic, L. A., Johnson, G. R., McCulloch. A. W., Odense, P., Pockling ton, R., Quilliam, M. A., Sim, P. G., Smith, J. C., Subba Roa, D. V., Todd, E. C. D., Walter, J. A., Wright, J. L. C. (1989). Pennate diatom Nitzschia pungens as the primary source of domoic acid, a toxin in shellfish from eastern Prince Edward Island. Canada. Can. J. Fish. Aquat. Sci. 46: 1203-1215

Bird, C. J., Wright, J. L. C. (1989). The shellfish toxin domoic acid. World Aquacult. 20:40-41

Bigelow, H. B., Leslie, M. (1930). Reconnaissance of the waters and plankton of Monterey Bay. July 1928. Bull Mus. Comp. Zool. Harv. Univ. 70: 427-581

Bolin, R. L., Abbott, D. P. (1963). Studies on the marine climate and phytoplankton of the central coastal area of California 1954-1960. Calif. Coop. Oceanic Fish. Invest. Rep 9: $23-45$

Chavez, F. P., Buck, K. R., Coale, K. H., Martin, J. H., DiTullio, G R., Welshmeyer, N. A., Jacobson, A. C., Barber, R. T. (1991) Growth rates, grazing, sinking and iron limitation of equatorial Pacific phytoplankton. Limnol. Oceanogr. 36: 1816-1833

Chelton, D. B. (1984). Seasonal variability of alongshore geostrophic velocity off Central California. J. geophys Res. 89: 8473-8486

Etchemendy, S. A., Davis, D. L. (1991). Designing an ROV for oceanographic research. Sea Technol. 32: 21-24

Frenguelli, J. (1939). Diatomeas del Golfo de San Matias. Rev Mus. La Plata, N. S. 2 (Secc. Bot.) 10:201-226

Fryxell, G. A., Garyà, S. A., Roelke, D. L. (1992). Auxospore formation in an Antarctic clone of Nitzschia subcurvata Hasle. Diatom Res. 6: 235-245

Garrison, D. L., Conrad, S. M., Eilers, P. P., Waldron, E. M. (1992)
Confirmation of domoic acid production by Pseudonitzschia australis (Bacillariophyceae) in culture. J. Phycol. (in press)

Hasle, G. R. (1965). Nitzschia and Fragilariopsis species studied in the light and electron microscopes II. The group Pseudonitzschia. Skr. nor. Vidensk-Akad. Oslo 1: 18:1-45

Hasle, G. R. (1972). The distribution of Nitzschia seriata Cleve and allied species. In: Simonsen, R. (ed.) First symposium on recent and fossil marine diatoms. Nova Hedwigia 39. $171-190$

Hasle, G. R., Fryxell, G. A. (1970). Diatoms: cleaning and mounting for light and electron microscopy. Trans. Am. Microsc. Soc. 89: 469-474

Hickey, B. H. (1979). The California current system: hypothesis and facts. Prog. Oceanogr. 8: 191-279

Honjo, S., Doherty, K. W. (1988). Large aperture time-series sediment traps; design objectives, construction and application. Deep Sea Res. 35: 133-149

Madhyastha, M. S., Novaczek, R. F., Ablett, R. F., Johnson, G., Nijjar, M. S., Sims, D. E. (1991). Uptake, distributions and clearance of domoic acid by mussels (Mytilus edulis L.). In: Gordon, D. C. (ed.) Proceedings of the second Canadian workshop on harmful marine algae. Can. Tech. Rep. Fish. Aquat. Sci. No. 1799: 13

Nelson, P. T. (1977). Wind stress and wind curl over the California Current. NOAA Tech. Rep. NMFS SSRF-714. U.S. Dept. Commerce

Peterson, W., Hutchings, L., Huggett, J., Largier, J. (1992) Anchovy spawning in relation to the biomass and the replenishment rate of their copepod prey on the western Agulhas Bank. S. Afr. J. mar. Sci. 12: (in press)

Reid, F. M. H. (1983). Biomass estimation of components of marine nanoplankton and picoplankton by the Utermöhl method. J. Plankton Res. 5: 235-251

Round, F. E., Crawford, R. M., Mann, D. G. (1990). The diatoms: biology and morphology of the genera. Cambridge University Press, Cambridge

Skogsberg, T. (1936). Hydrography of the Monterey Bay, California. Thermal conditions. Trans. Am. phil. Soc. 29 $1-152$

Stenzel, L. E., Carter, G. W. Ainley, D. G. (1988). Seabird mortality in California as witnessed through 14 years of beached bird censuses. Pt Reyes Bird Observatory, Stinson Beach, CA

Strub, P. I., Allen, J. S., Huyer, A., Smith, R. L. (1987) Seasonal cycles of currents, temperature, winds and sea level over the northeast Pacific continental shelf: $35 \mathrm{~N}$ to 48N. J. geophys. Res. 92: 1507-1526

Subba-Rao, D. V., Quilliam, M. A., Pocklington, R. (1988). Domoic acid-a neurotoxic amino acid produced by the marine diatom Nitzschia pungens in culture. Can. J. Fish. Aquat. Sci. 45: 2076-2079

Takemoto, T., Daigo, K. (1958). Constituents of Chondria armata. Chem. Pharm. Bull. 6: 578-580

Wild, P. (1990). 1989 commercial fish landing and value and a review of 1979-1988. Monterey Bay commercial fisheries report: a newsletter to the commercial fishing industry. Calif. Dept Fish and Game, Monterey. No. 1, August 1990

Windhust, A., Wright, J. L. C. (1991). The effects of domoic acid and Nitzschia pungens on zooplankton: Toxicity, feeding and uptake. In: Gordon, D. C. (ed.) Proceedings of the second Canadian workshop on harmful marine algae. Can. Tech. Rep. Fish. Aquat. Sci. No. 1799: 29

Work, T. M., Beale, A. M., Fritz, L., Quilliam, M. A., Silver, M. W., Buck, K. R., Wright, J. L. (1992). Domoic acid intoxification of brown pelicans and cormorants in Santa Cruz, California. In: Smayda, T J. (ed.) Fifth international conference on toxic phytoplankton. Elsevier (in press) 